\title{
Vehicle Washing (Doorsmeer) Wastewater Treatment using Flotation Electroagulation Combination
}

\author{
Riyanto Suprawihadi ${ }^{1}$, Dina Indarsita ${ }^{2}$, and Salbiah Khamaruddin ${ }^{3^{*}}$ \\ ${ }^{1}$ Health Polytechnic of Medan, Indonesia \\ Email:nyonk.hawie [AT] gmail.com \\ ${ }^{2}$ Health Polytechnic of Medan, Indonesia \\ Email: dindarsita [AT] gmail.com \\ ${ }^{3}$ Health Polytechnic of Jakarta III \\ Jakarta, Indonesia \\ *Corresponding author's email: salbiah.khamaruddin80 [AT] gmail.com
}

\begin{abstract}
Vehicle washing business services in the current era are growing in numbers, both simple and those that have used technology. As a consequence, the production of wastewater more and more, which if not controlled will have an impact on environmental pollution. Conventional wastewater treatment technology is sometimes less effective because it requires chemicals in the process and requires relatively longer, so the need for land to build a treatment unit is relatively wider. To provide an alternative treatment process that is simpler and has good results and does not require large tracts of land, it is necessary to develop electro-coagulation technology combined with flotation. Electrocoagulation is the process of clumping and precipitation of fine particles contained in water by using electrical energy. This study was to determine the ability of electrocoagulation-flotation technology in decreasing the parameters of COD, detergents, and oil in motor vehicle washing wastewater based on the type of electrodes used at 12 and 24-volt electric voltages with contact times of 30 and 60 minutes. This study is an experimental study with a "pre and post-test group design" design. The results showed that the combination of electrocoagulation-flotation at 24-volt voltage and 60 minutes contact time with aluminum electrodes could reduce COD $82.7 \%$, oil $46.5 \%$, and detergent $68.9 \%$. Whereas with iron electrodes the COD decreased by $81.1 \%$, oil by $43.7 \%$ and detergents by $65.1 \%$. With an average reduction, aluminum electrodes are better than iron electrodes. Although aluminum and iron electrodes are better, statistically the two are not different ( $p<0.05)$, this shows that there is no difference in the ability to decrease test parameters. Other than that, the longer the contact time, the greater the decrease in test parameters. The conclusion is that the electrocoagulation-flotation combination method can be used to reduce the COD, oil/fat and detergent parameters in motor vehicle washing wastewater. The results of this study are expected to be applied to motor vehicle washing activities by utilizing iron waste as an electrode.
\end{abstract}

Keywords ---- Wastewater, washing of motor vehicles, Electrocoagulation-flotation, electrodes, aluminum, iron

\section{INTRODUCTION}

One of the human activities in meeting the economic needs of the family is a motor vehicle washing service business, better known as "doorsmeer." The service business in the current era is growing in numbers both simple and those that have used technology. The development of the service business includes the development of motorized vehicle ownership both four-wheeled and two-wheeled vehicles.

With the development of the doormeer service business has consequences for the production of waste water more and more, which if not controlled will have an impact on environmental pollution. The characteristics of wastewater from motor vehicle washing generally contain detergents (ionic surfactants), oil, metals and soil solids. Waste generated from car washes has a COD concentration ranging from 141-1019 mg / L based on several results measuring the characteristics of wastewater from car washing. While the amount of clean water used in the service business is around 4350 liters / day to wash 40 cars (Hakim, 2011) which will be disposed of as waste water as a whole

The content of surfactants and oil when discharged into water bodies can cause a decrease in the quality of water bodies and cause unpleasant odors because of the nature of detergents and oils that are difficult to decompose in water bodies. The two most important ingredients of detergent-forming surfactants and builders are identified as having direct and indirect effects on humans and the environment. Effects on health, especially nitrosamine compounds that occur are known to be carcinogenic, can cause cancer (Widiyani, 2010). While sodium lauryl sulfate (SLS) compounds are known to cause skin irritation, slow the healing process and cause cataracts in adult eyes. 
The doorsmeer service business activities in general do not yet have a wastewater treatment unit, so the washing water is discharged directly into the gutters connected to the municipal gutters. This can pose a risk of pollution to the environment if the disposal is not controlled.

Wastewater treatment technology that has been applied generally in the form of coagulation-flocculation through the addition of chemicals, sedimentation, neutralization, activated sludge and anaerobic tubs. This technology is commonly used in the treatment of all types of wastewater. But sometimes less effective when applied to types of wastewater with specific ingredients such as heavy metals, detergents and oils.

Although conventional technology such as the above can be used in the treatment of motor vehicle washing wastewater, it still requires chemicals in the process and requires a relatively longer time, so the need for land to build a processing unit is relatively wider. While the existing motor vehicle cleaning services business is generally located on relatively limited land and in urban areas.

To provide an alternative treatment process that is simpler and produces good results and does not require large tracts of land, it is necessary to develop electro-coagulation technology combined with flotation. Electrocoagulation is the process of clumping and settling of fine particles contained in water by using electrical energy. This electrocoagulation is a more advanced technology compared to coagulation methods that still use conventional coagulants (Gunawan, D.A, 2016.

Prinsip dasar dari elektrokoagulasi adalah reaksi reduksi dan oksidasi (redoks). Dalam suatu sel elektrokoagulasi, peristiwa oksidasi terjadi di elektroda (+) yaitu anoda, sedangkan reduksi terjadi di elektroda (-) yaitu katoda. Dengan digunakannya kombinasi teknologi elektrokoagulasi dan flotasi ini, diharapkan mampu menurunkan parameter bahan pencemar yang meliputi COD, detergen, dan minyak hingga memenuhi baku mutu lingkungan yang telah ditetapkan. Kombinasi teknologi ini cukup sederhana karena hanya mengandalkan proses fisika dengan kebutuhan lahan yang relatif kecil.

The basic principle of electrocoagulation is the reduction and oxidation (redox) reaction. In an electrocoagulation cell, the oxidation event occurs at the electrode (+), which is the anode, while the reduction occurs at the electrode (-), which is the cathode. By using this combination of electrocoagulation and flotation technology, it is expected to reduce the parameters of pollutants which include COD, detergents, and oil to meet established environmental quality standards. This technology combination is quite simple because it only relies on physics processes with relatively small land requirements

Based on the description above, the problem that needs to be studied in this research is how much the ability of electrocoagulation-flotation technology in reducing the parameters of COD, detergent, and oil in motor vehicle washing wastewater based on the type of electrodes used.

\section{METHODS}

This type of research is an experimental study with a Pre-post Test Group Design. Where the object is divided into two treatment groups based on the type of electrode, namely one treatment group uses aluminum metal electrodes and one other group uses ferrous metals, without a control group.

Experiments carried out by the continuous method at different electrical voltages with flow velocity according to the contact time. After the allotted time then a variable is tried in the two groups. The difference in results between the two groups explains the difference in treatment ability

The research design will be carried out as below:

REACTOR

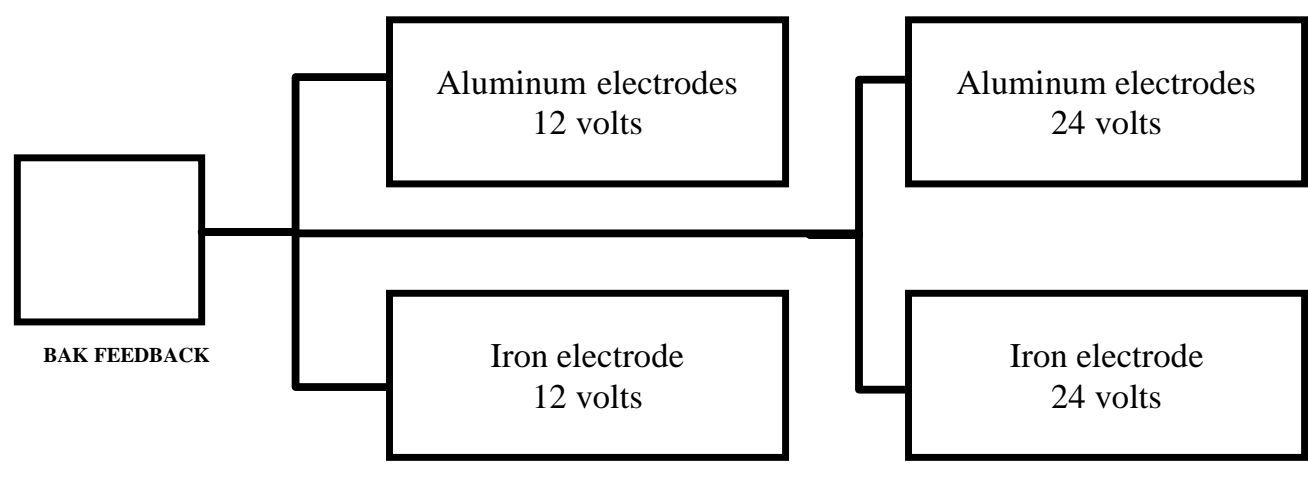

Figure 1. Schematic of the Research Process

This research was conducted with a monopolar method for each type of electrode at 5 Amp strong current with a voltage of 12 volts and 24 volts, during contact time of 30 minutes and 60 minutes at a flow rate of 1 liter / minute. Replication was carried out 3 times in each aid group. 
The object of research is motor vehicle washing wastewater which includes COD, oil and detergent.

\section{RESULTS}

Table 1. Decreasing the parameters of Wastewater Washing Motorized Vehicles using Electrocoagulation-Flotation Combinations on Aluminum Electrode Types with 12 Volt Voltage based on contact time.

\begin{tabular}{|c|c|c|c|c|c|c|c|c|c|}
\hline \multirow{2}{*}{ No } & \multirow{2}{*}{ Parameter } & \multicolumn{2}{|c|}{$\begin{array}{c}\text { Contact Time } \\
\text { (30 minutes) }\end{array}$} & \multicolumn{2}{|c|}{ Decrease } & \multicolumn{2}{|c|}{$\begin{array}{c}\text { Contact Time } \\
(60 \text { minutes })\end{array}$} & \multicolumn{2}{|c|}{ Decrease } \\
\hline & & $\begin{array}{l}\text { Before } \\
(\mathrm{Mg} / \mathrm{l})\end{array}$ & $\begin{array}{c}\text { After } \\
(\mathrm{Mg} / \mathrm{l})\end{array}$ & $\mathrm{Mg} / \mathrm{l}$ & $\%$ & $\begin{array}{l}\text { Before } \\
(\mathrm{Mg} / \mathrm{l})\end{array}$ & $\begin{array}{c}\text { After } \\
(\mathrm{Mg} / \mathrm{l})\end{array}$ & $\mathrm{Mg} / \mathrm{l}$ & $\%$ \\
\hline 1 & COD & 69,6 & 31,5 & 38,1 & 54,7 & 69,6 & 17,4 & 52,2 & 75,0 \\
\hline 2 & Oil / Fat & 19,3 & 13,0 & 6,3 & 32,6 & 19,3 & 6,9 & 12,4 & 64,3 \\
\hline 3 & Detergent & 190,7 & 165,4 & 25,3 & 13,3 & 190,7 & 70,3 & 120,4 & 63,1 \\
\hline
\end{tabular}

Table 1 shows that by using aluminum electrodes at 12 volt voltage, the average COD reduction was $38,1 \mathrm{mg} / 1$ $(54,7 \%)$ at 30 minutes contact time and at 60 minutes contact time the average COD reduction was 52,2 mg / $1(75 \%)$. The average reduction in oil is smaller at $6,3 \mathrm{mg} / 1(32,6 \%)$ at a contact time of 30 minutes, but at contact for 60 minutes the decrease in oil / fat is greater by an average of 12,4 $\mathrm{mg} / 1(64,3 \%)$. The percentage decrease in detergent is smaller than the previous two parameters, namely $13,3 \%$ with an average decrease of $25,3 \mathrm{mg} / 1$ at 30 minutes contact time. And at contact time of 60 minutes, the average reduction was $120.4 \mathrm{mg} / 1(63,1 \%)$.

Table 2. Decreasing the parameters of Wastewater Washing Motorized Vehicles using a Combination of Electrocoagulation-Flotation on Iron Electrode Types with 12 Volt Voltage based on contact time.

\begin{tabular}{|c|c|c|c|c|c|c|c|c|c|}
\hline \multirow{2}{*}{ No } & \multirow{2}{*}{ Parameter } & \multicolumn{2}{|c|}{$\begin{array}{l}\text { Contact Time } \\
\text { (30 minutes) }\end{array}$} & \multicolumn{2}{|c|}{ Decrease } & \multicolumn{2}{|c|}{$\begin{array}{l}\text { Contact Time } \\
\text { (60 minutes) }\end{array}$} & \multicolumn{2}{|c|}{ Decrease } \\
\hline & & $\begin{array}{l}\text { Before } \\
(\mathrm{Mg} / \mathrm{l})\end{array}$ & $\begin{array}{l}\text { After } \\
(\mathrm{Mg} / \mathrm{l})\end{array}$ & $\mathrm{Mg} / \mathrm{l}$ & $\%$ & $\begin{array}{l}\text { Before } \\
(\mathrm{Mg} / \mathrm{l})\end{array}$ & $\begin{array}{c}\text { After } \\
(\mathrm{Mg} / \mathrm{l})\end{array}$ & $\mathrm{Mg} / \mathrm{l}$ & $\%$ \\
\hline 1 & COD & 69,6 & 37,9 & 31,7 & 45,5 & 69,6 & 21,6 & 48,0 & 69,0 \\
\hline 2 & Oil / Fat & 19,3 & 14,2 & 5,1 & 26,4 & 19,3 & 10,6 & 8,7 & 45,1 \\
\hline 3 & Deterjent & 190,7 & 179,9 & 10,8 & 5,7 & 190,7 & 79,3 & 111,4 & 58,4 \\
\hline
\end{tabular}

Table 2 shows that the decrease in parameters on the use of iron electrodes and 12 volt voltage, the average COD reduction was $31.7 \mathrm{mg} / 1(45.5 \%)$ at 30 minutes contact time and at 60 minutes contact time the average COD reduction $48 \mathrm{mg} / 1(69 \%)$. Average decrease in oil / fat $5.1 \mathrm{mg} / 1(26.4 \%)$ at 30 minutes contact time, and at 60 minutes contact time an average of $8.7 \mathrm{mg} / 1(45.1 \%)$. In the detergent parameter, the percentage decrease was $5.7 \%$ with an average decrease of $10.8 \mathrm{mg} / \mathrm{l}$ over a 30 minute contact duration and at 60 minutes contact time, the average decrease was $111.4 \mathrm{mg} / 1$ $(58.4 \%)$.

Graph 1. Percentage reduction in COD levels before and after

Flotation Electrocoagulation at 12 Volt Voltage based on
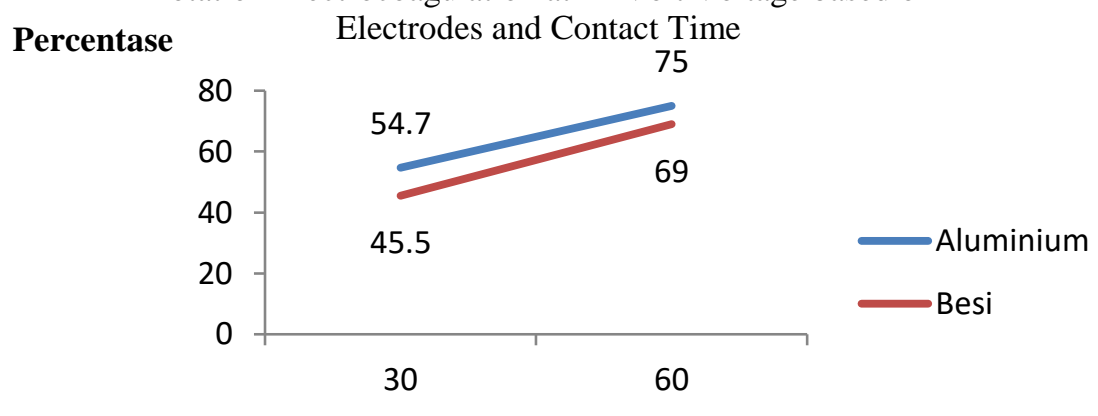

Contact Time 
Graph 2. Percentage of Decrease in Oil Levels before and after Electrocoagulation Flotation at 12 Volt Voltage based on

Electrodes and Contact Time

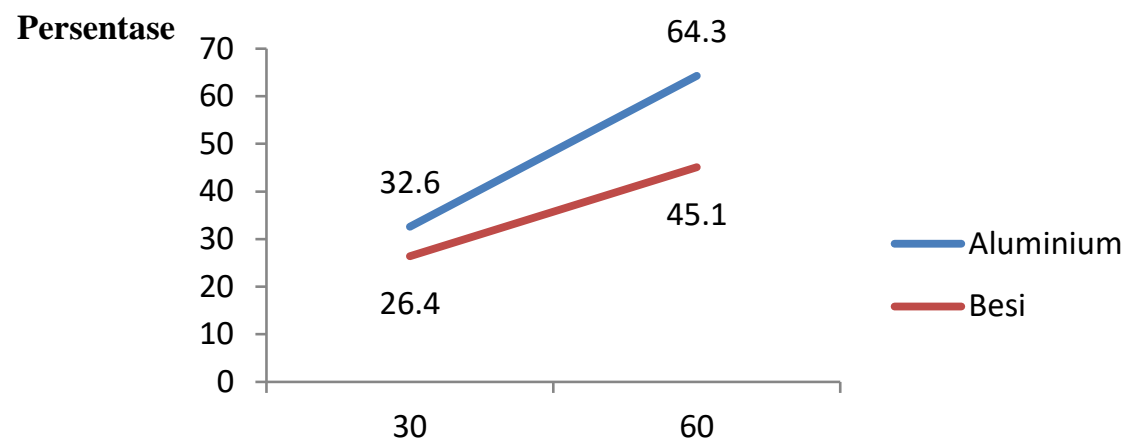

Contact Time

Graph 3. Percentage Decrease in Detergent Levels before and after Flotation Electrocoagulation at 12 Volt Voltage Based on Electrodes and Contact Time

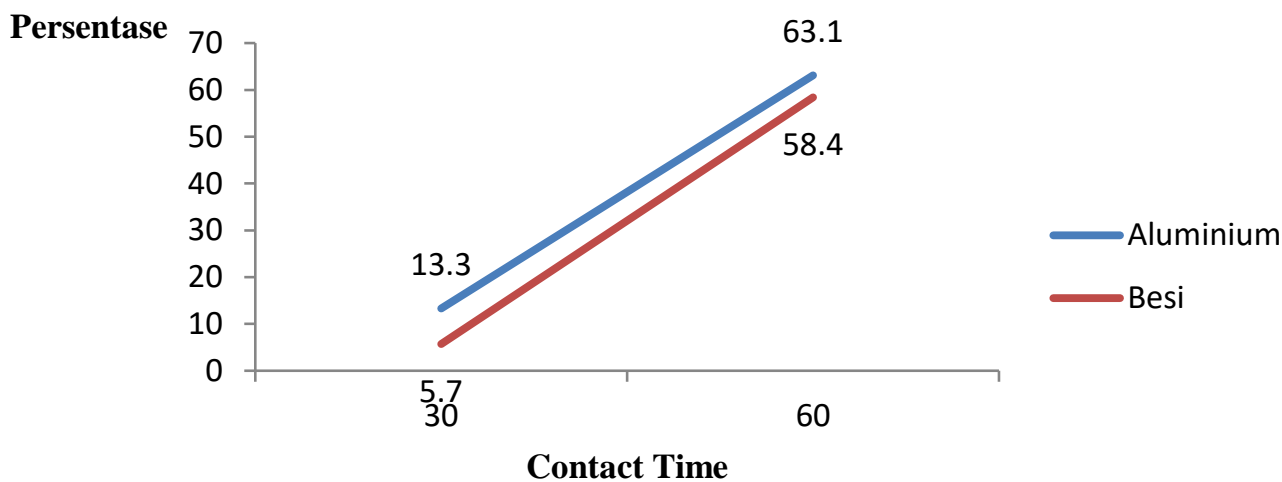

The three graphs above it can be seen that there is a decrease in the three parameters of the motor vehicle washing wastewater test after the flotation electrocoagulation process is carried out at a 12 volt electrical voltage. In the COD and detergent parameters, the percentage of reduction shows the same pattern between the aluminum electrode and the iron electrode for both the contact time of 30 minutes and 60 minutes. Then in the oil parameter there is a difference in the percentage pattern of the decrease, where for the iron electrode at the time of contact the pattern is not like the aluminum electrode. In the observation during the process, it appears that the oil collects and is bound to the aluminum electrode, while the iron electrode, the oil / fat still floats on the surface of the water. Overall, it can be seen that the use of aluminum electrodes is greater than the percentage reduction in the three test parameters compared to the use of iron electrodes both for contact time of 30 minutes and contact time of 60 minutes. The three graphs also illustrate that the longer the contact time, the greater the percentage reduction in the three test parameters.

Table 3. Average Decrease in parameters of Wastewater Washing Motorized Vehicles Using ElectrocoagulationFlotation Combinations on Aluminum Electrode Types with 24 Volt Voltage based on contact time.

\begin{tabular}{lllllccccc}
\hline \multirow{2}{*}{ Parameter } & \multicolumn{2}{c}{$\begin{array}{c}\text { Contact Time } \\
(30 \text { minutes })\end{array}$} & \multicolumn{2}{c}{ Decrease } & \multicolumn{2}{c}{$\begin{array}{c}\text { Contact Time } \\
(60 \text { minutes })\end{array}$} & \multicolumn{2}{c}{ Decrease } \\
\cline { 2 - 9 } & $\begin{array}{c}\text { Before } \\
(\mathrm{Mg} / \mathrm{l})\end{array}$ & $\begin{array}{c}\text { After } \\
(\mathrm{Mg} / \mathrm{l})\end{array}$ & $\mathrm{Mg} / \mathrm{l}$ & $\%$ & $\begin{array}{c}\text { Before } \\
(\mathrm{Mg} / \mathrm{l})\end{array}$ & $\begin{array}{c}\text { After } \\
(\mathrm{Mg} / \mathrm{l})\end{array}$ & $\mathrm{Mg} / \mathrm{l}$ & $\%$ \\
\hline COD & 69,4 & 57,4 & 12,0 & 17,3 & 69,4 & 12,0 & 57,4 & 82,7 \\
\hline Oil & 14,2 & 10,4 & 3,8 & 26,8 & 14,2 & 7,6 & 6,6 & 46,5 \\
\hline Deterjent & 197,5 & 124,9 & 72,6 & 36,8 & 197,5 & 61,3 & 136,2 & 68,9 \\
\hline
\end{tabular}


Table 3 shows that the decrease in parameters on the use of aluminum electrodes and 24 volt voltage, the average COD reduction was $12 \mathrm{mg} / 1(17.3 \%)$ at 30 minutes contact time and at 60 minutes contact time the average COD decrease was $57.4 \mathrm{mg} / 1(82.7 \%)$. In the oil parameter the average reduction was $3.8 \mathrm{mg} / 1(26.8 \%)$ at the contact time of $30 \mathrm{minutes}$, and at the contact time of 60 minutes the average oil / fat reduction was $6.6 \mathrm{mg} / 1(46.5 \%)$. Then in the detergent parameter, the percentage reduction was $36.8 \%$ with an average decrease of $72.6 \mathrm{mg} / 1$ over a 30 minute contact duration then at 60 minutes contact time, the average reduction was $136.2 \mathrm{mg} / 1(68.9 \%)$.

Table 4. Decreasing Data on Wastewater Washing parameters of Motorized Vehicles using ElectrocoagulationFlotation Combinations on Iron Electrode Types with 24 Volt Voltage based on contact time.

\begin{tabular}{lcccccccc}
\hline \multirow{2}{*}{ Parameter } & \multicolumn{2}{c}{$\begin{array}{c}\text { Contact Time } \\
\text { minutes })\end{array}$} & \multicolumn{2}{c}{ Decrease } & \multicolumn{2}{c}{$\begin{array}{c}\text { Contact Time } \\
\text { minutes })\end{array}$} & \multicolumn{2}{c}{ Decrease } \\
\cline { 2 - 9 } & $\begin{array}{c}\text { Before } \\
(\mathrm{Mg} / \mathrm{l})\end{array}$ & $\begin{array}{c}\text { After } \\
(\mathrm{Mg} / \mathrm{l})\end{array}$ & $\mathrm{Mg} / \mathrm{l}$ & $\%$ & $\begin{array}{c}\text { Before } \\
(\mathrm{Mg} / \mathrm{l})\end{array}$ & $\begin{array}{c}\text { After } \\
(\mathrm{Mg} / \mathrm{l})\end{array}$ & $\mathrm{Mg} / 1$ & $\%$ \\
\hline COD & 69,4 & 63,1 & 6,3 & 9,1 & 69,4 & 13,1 & 56,3 & 81,1 \\
\hline Oil & 14,2 & 13,4 & 0,8 & 5,6 & 14,2 & 8,0 & 6,2 & 43,7 \\
\hline Detergent & 197,5 & 133,6 & 63,8 & 32,3 & 197,5 & 68,9 & 128,5 & 65,1 \\
\hline
\end{tabular}

Table 4 shows that the average COD decrease was $6.3 \mathrm{mg} / 1(9.1 \%)$ at 30 minutes contact duration and at 60 minutes contact duration the average COD decrease was $56.3 \mathrm{mg} / 1(81.1 \%)$ at voltage of 24 volts. For oil / fat parameters the average reduction was $0.8 \mathrm{mg} / 1(5.6 \%)$ at a contact time of 30 minutes, and at a contact time of 60 minutes the average oil reduction was $6.2 \mathrm{mg} / 1(43.7 \%)$. In the detergent parameter, the percentage of reduction was $32.3 \%$ with an average decrease of $63.8 \mathrm{mg} / 1$ in contact time 30 minutes then in contact time 60 minutes, an average decrease of $128.5 \mathrm{mg} / 1$ $(65.1 \%)$.

Graph 4. Percentage reduction in COD levels before and after

Electrocoagulation Flotation at 24 Volt Voltage based on

Electrodes and Contact Time

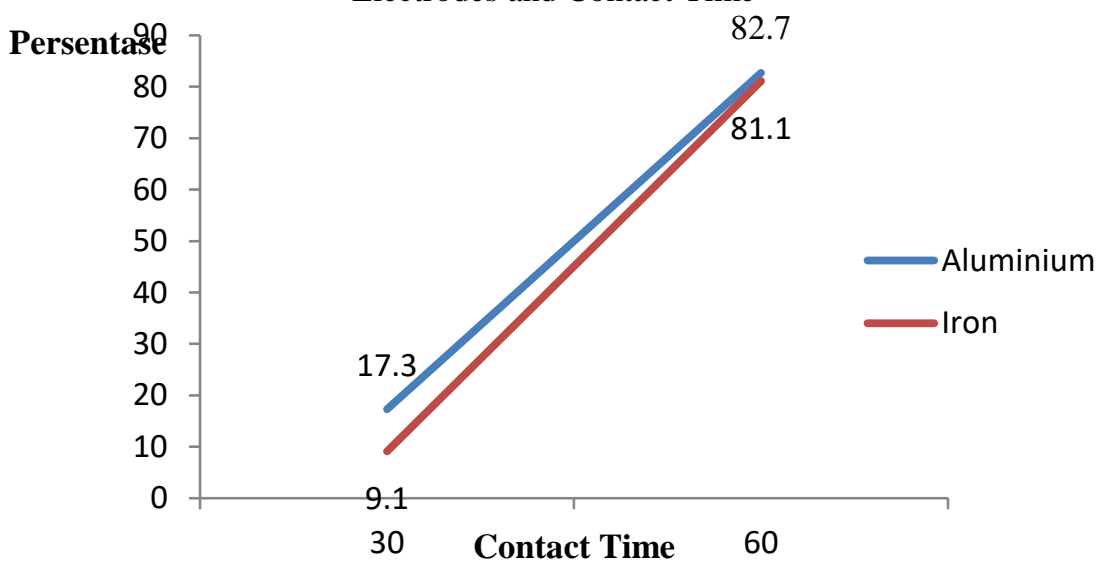


Graph 5. Percentage reduction in Oil / fat content before and after Electrocoagulation Flotation at 24 Volt Voltage based on Electrodes and Contact Time

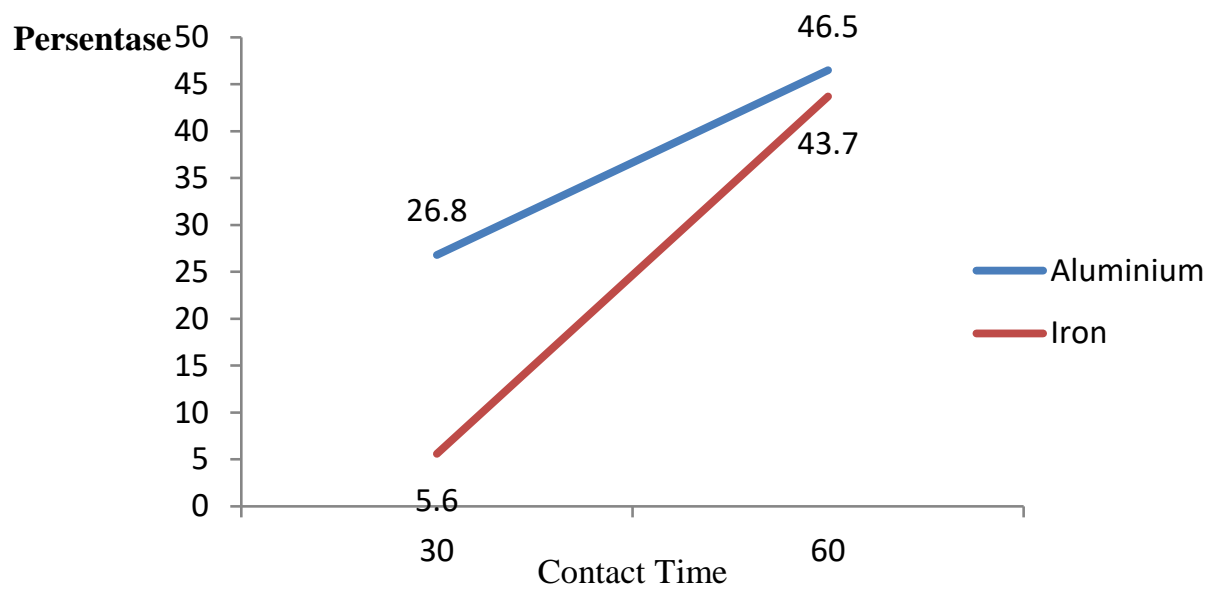

Graph 6.Percentage of Detergent Level Decrease before and after

Electrocoagulation Flotation at 24 Volt Voltage based on Electrodes and Contact Time

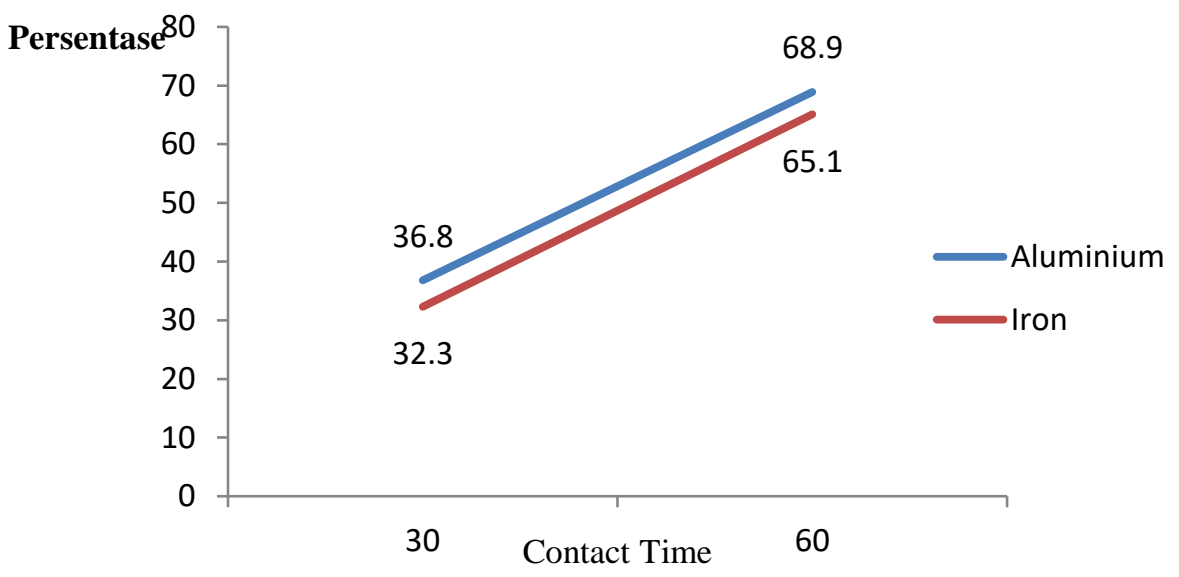

The percentage reduction pattern of the three test parameters has almost the same pattern between the contact time of 30 minutes and 60 minutes.

Table 5. Results of Analysis of Differences in Drop in Test Parameters based on Duration of Contact

\begin{tabular}{llllllll}
\hline Parameter & $\begin{array}{l}\text { Contact } \\
\text { Time }\end{array}$ & Mean & F & Sig. & t & df & Sig. (2-tailed) \\
\hline COD & $\begin{array}{l}30 \text { minutes } \\
60 \text { minutes }\end{array}$ & $\begin{array}{l}22,02 \\
53,60\end{array}$ & 70,77 & 0,000 & $-7,569$ & 22 & 0,0001 \\
\hline Oil / fat & $\begin{array}{l}30 \text { minutes } \\
60 \text { minutes }\end{array}$ & $\begin{array}{l}4,01 \\
8,47\end{array}$ & 1,923 & 0,179 & $-4,404$ & 22 & 0,0001 \\
\hline Deterjen & $\begin{array}{l}30 \text { minutes } \\
60 \text { minutes }\end{array}$ & $\begin{array}{l}43,12 \\
124,10\end{array}$ & 54,13 & 0,000 & $-9,779$ & 22 & 0,0001
\end{tabular}

Table 5 shows that the length of contact time plays a role in decreasing the test parameters in motor vehicle washing wastewater. It is shown that in each test parameter there is a significant difference $(p<0.05)$ between the length of contact time of 30 minutes and 60 minutes. 
Table 6. Analysis Results of Differences in Drop in Test Parameters based on the Amount of Electric Voltage

\begin{tabular}{|c|c|c|c|c|c|c|c|}
\hline Parameter & Voltage & Mean & $\mathrm{F}$ & Sig. & $\mathrm{t}$ & $\mathrm{df}$ & Sig. (2-tailed) \\
\hline COD & $\begin{array}{l}12 \text { volt } \\
24 \text { volt }\end{array}$ & $\begin{array}{l}42,51 \\
33,15\end{array}$ & 217,556 & 0,000 & 1,219 & 22 & 0,0001 \\
\hline Oil / fat & $\begin{array}{l}12 \text { volt } \\
24 \text { volt }\end{array}$ & $\begin{array}{l}8,13 \\
4,34\end{array}$ & 1,613 & 0,217 & 3,358 & 22 & 0,0001 \\
\hline Deterjen & $\frac{12 \text { volt }}{24 \text { volt }}$ & $\begin{array}{c}\frac{66,96}{100,26} \\
\end{array}$ & 54,126 & 0,000 & $-1,873$ & 22 & 0,0001 \\
\hline
\end{tabular}

From table 6 it can be seen that the difference in the magnitude of the electric voltage used has no effect in decreasing the test parameters in motor vehicle washing waste water. This shows that for each test parameter there is no significant difference $(\mathrm{p}>0.05)$ between the 12 volt and 24 volt voltages, except for the oil / grease test parameters.

Table 7. Analysis Results of Differences in Drop in Test Parameters between Aluminum Electrodes and Iron Electrodes

\begin{tabular}{|c|c|c|c|c|c|c|c|}
\hline $\begin{array}{l}\text { Parameter } \\
\text { COD }\end{array}$ & $\begin{array}{l}\text { Elektroda } \\
\text { Aluminium } \\
\text { Iron } \\
\end{array}$ & $\begin{array}{l}\text { Mean } \\
40,09 \\
35,58 \\
\end{array}$ & 0,142 & $\begin{array}{l}\text { Sig. } \\
0,710\end{array}$ & 0,573 & 22 & $\begin{array}{c}\text { Sig. (2-tailed) } \\
0,573\end{array}$ \\
\hline Oil/fat & $\begin{array}{l}\text { Aluminium } \\
\text { Iron }\end{array}$ & $\begin{array}{l}7,28 \\
5,20\end{array}$ & 0,093 & 0,763 & 1,576 & 22 & 0,129 \\
\hline Deterjent & $\begin{array}{l}\text { Aluminium } \\
\text { Iron }\end{array}$ & $\begin{array}{l}88,60 \\
78,63\end{array}$ & 0,043 & 0,838 & 0,524 & 22 & 0,606 \\
\hline
\end{tabular}

Table 7 shows that the parameters of COD, oil and detergent have homogeneous variances ( $>>0.05)$, so that the difference test can be performed. The results of the analysis of the difference in the average decrease in the test parameters between the aluminum electrode and the iron electrode turned out to be no difference ( $p>0.05$ ), both for COD, oil / fat and detergent parameters. This shows that the two types of electrodes, namely aluminum and iron, have the ability to reduce the parameters of motor vehicle washing wastewater.

\section{DISCUSSION}

Electrocoagulation is a method of electrochemical water treatment where the anode releases an active coagulant in the form of metal ions into the solution, while at the cathode there is an electrolytic reaction in the form of releasing hydrogen gas (Holt et al, 2004).

This research was conducted with a monopolar configuration where the anode pole and cathode pole were one type of metal as the electrode using a continuous method with a flow rate of 1 liter / minute. The two types of electrodes used are aluminum metal and ferrous metal. The results showed that the electrocoagulation-flotation combination could reduce the parameters of motor vehicle washing waste water using both aluminum and iron electrodes. The value of the average decrease between the parameters of COD, oil/fat and detergent test was different. This difference is related to the contact time, the longer the contact time, the greater the percentage of decreasing test parameters, namely COD, oil/fat and detergent.

The ability of electrocoagulation treatment in decreasing test parameters is due to electro chemical processes, where the presence of an electric current at the anode results in an oxidation reaction to the anions (negative ions), where an anode made of aluminum metal will undergo an oxidation reaction to form $\mathrm{Al} 3+$ ions and will bind $\mathrm{OH}$ ions to form flocks $\mathrm{Al}(\mathrm{OH}) 3$ which will bind the suspended particles and the metal content that is not deposited will be bound to the cathode rod. This condition allows the decrease in test parameters such as COD, oil and detergents (surfactants). The removal mechanism that commonly occurs in the electrocoagulation process is divided into three main factors, namely the formation of coagulants due to the electrolytic oxidation process of the electrodes; destabilization of suspended particle contaminants and breakdown of emulsions and aggregation of destabilized results to form floc (Mollah, 2004). Likewise, the iron electrode will undergo an oxidation reaction to form $\mathrm{Fe} 3+$ ions and will bind $\mathrm{OH}$ - ions to form $\mathrm{Fe}(\mathrm{OH}) 3$ flocks.

Statistically, the type of electrode used does not differ from ferrous metal in reducing (reducing) the parameters of COD, oil and detergent in motorized vehicle washing wastewater. Decrease in test parameters for COD, oil / fat and detergent based on the results of the study shown in the graph shows that the longer the contact time, the greater the allowance for test parameters, and vice versa. The longer the contact time applied during the electrocoagulation process, the interaction between particles occurs so that the size increases and the quality of the treated water is getting better. The existence of an increase in stress in the allowance for the test parameters was not significant for COD and detergents, which 
means that the use of a higher voltage did not have a big effect on COD removal. The oil / fat parameter looks significant. The physical changes that can be observed directly are that on the electrodes, both aluminum and iron, there is an attachment of oil / grease, which if the contact time is extended, corrosion will occur on the plate used.

Corrosion is the process of oxidizing a metal with air or other electrolytes, where air or electrolytes are reduced. Copper plate corrosion occurs due to the release of copper ions into the waste water. The longer the copper plate is used, the greater the corrosion of the plate. In theory, the longer the electrocoagulation process takes, the more $\mathrm{H} 2$ and $\mathrm{OH}$ formation will be so that the more complexes that bind pollutants and the amount of hydrogen gas. Thus the number of pollutants in the solution will decrease. The decrease in oil / fat concentration through the electrocoagulation process shows the same pattern as the COD removal process and detergent, namely the longer the contact time, the better the decrease in test parameters. There is an allowance for the test parameters in the electrocoagulation process due to adsorption on the surface of the particles to form a hydropobic surface which causes the particles in the waste water to rise to the surface with the help of gas bubbles formed and the flotation process using an aerator. With the longer contact time, the resulting gas bubbles will increase so that the ability of electrocoagulation to set aside test parameters also increases (Rachmawati, B, et al., 2014).

In a continuous (continuous) electrocoagulation system application with a variation of contact time of 60 minutes and a voltage of 24 volts gives the best results on aluminum electrodes with COD removal rate of $82.7 \%$, oil / grease of $46.5 \%$ and detergent of $68.9 \%$. While the iron electrode with the same contact time and voltage removal rate of COD was $81.1 \%$, oil / fat was $43.7 \%$ and detergent was $65.1 \%$. This is in accordance with the results of Ansiha Nur's research where at the contact time of 975 seconds (60 minutes) COD removal rate was $89.09 \%$ and oil / fat was $89.79 \%$ (Nur, 2014).

\section{CONCLUSION}

1. The combination electrocoagulation-monopolar flotation method can be used as an alternative in motorized vehicle washing wastewater treatment with the ability to reduce COD parameters to $82 \%$; $64 \%$ decrease in oil / grease and $69 \%$ decrease in detergent.

2. Aluminum metal electrodes on average have the ability to reduce parameters greater than iron electrodes, but statistically the two metals do not differ in their ability to reduce COD, oil / grease and detergent parameters ( $\mathrm{p}$ $<0.05)$.

3. There is a difference in the decrease in test parameters $(\mathrm{p}<0.05)$ based on the length of contact time, the longer the contact time, the greater the decrease in the test parameters.

4. There is no difference in the amount of voltage between 12 volts and 24 volts in deriving the test parameters

\section{RECOMENDATION}

The electrocoagulation-flotation combination method using aluminum and iron as electrodes in a monopolar manner with a minimum contact time of 60 minutes and a voltage of 24 volts and a current density of 5 amperes can be used for handling motor vehicle washing wastewater because it can shorten the processing process.

\section{ACKNOWLEDGEMENT}

The author would like to thank the Poltekkes Kemenkes Medan and the Owner of Doorsmer and all individuals involved for their contribution and assistance in the data collection process.

\section{REFERENCES}

[1] Benefield, L. D., Judkins J. F. and Weand, B. L. 1982. Process Chemistry for Water and Wastewater Treatment. Prentice Hall Inc

[2] Duffey, J.G. 1983. Electrochemical Removal of Heavy Metals from Wastewater, Product Finishing, p. 72, August 1983

[3] Fraco, N. B. 1974. Electrochemical Removal of Heavy Metal from Acid Mine Drainage. Enviromental Protection Agency Report EPA-670 12-74-023. May 1974

[4] Gunawan,DA. 2016. Elektrokoagulasi Menggunakan Aluminium sebagai Pretreatment pada Mikrofiltrasi Air Permukaan yang mengandung MOM. Teknik Kimia. Institut Teknologi Bandung. 
[5] Hakim, FR. 2011. Penelitian Pengolahan Limbah Jasa Pencucian Mobil dengan Koagulasi-Flokulasi Secara Batch. Tugas Akhir Teknik Lingkungan ITS. Surabaya

[6] Lin, Shundar. 2001, Water and Wastewater Calculation Manual, McGraw-Hill, USA

[7] Masthura dan Jumiati. E 2017. Peningkatan Kualitas Air Menggunakan Metode Elektrokoagulasi dan Filter Karbon. Jurnal Ilmu Fisika dan Teknologi,Vol.1, No.2,2017, 1-6.

[8] Metcalf, Eddy. 1991. Wastewater Engineering. third edition. McGraw - Hill Inc. New York

[9] Mollah, MYA.2004. Electrocoagulation (EC)-Science and Applications. Journal of Hazardous Materials, B114:199-210

[10] Nur, A dan Agus Jatnika. 2014. Aplikasi Elektrokoagulasi Pasangan Elektroda Aluminium Pada Proses Daur Ulang Grey Water Hotel. Jurnal Teknik Lingkungan Volume 20 Nomor 1, Mei 2014 (Hal 58-67). Program Studi Teknik Lingkungan Fakultas Teknik Sipil dan Lingkungan, Institut Teknologi Bandung. Bandung

[11] Peter, H. Geoffrey, B and Mitchell, C. 2006. Electrocoagulation As a Wastewater Treatment, Departement of Chemical Engeneering. The University of Sydney. New South Wales

[12] Putri, A. 2018. Penurunan Chemical Oxygen Demand (COD) pada Limbah Rumah Sakit dengan Metode Elektrokoagulasi Menggunakan Anoda dan Katoda Alumunium (Al). Skripsi Fakultas MIPA. Universitas Islam Indonesia. Yogyakarta

[13] Rachmawati, B dkk.2014. Proses Elektrokoagulasi Pengolahan Limbah Laundry. Jurnal Ilmiah Teknik Lingkungan Vol. 6 No. 1. Program Studi Teknik Lingkungan, Fakultas Teknik Sipil dan Perencanaan Universitas Pembangunan Nasional "Veteran" Jawa Timur. Surabaya

[14] Renk, R. R. 1989. Treatment of hazardous wastewater by electrocoagulation. In: 3rd Annual Conference Proceedings (1989). Colorado Hazardous Waste Management Society

[15] Widiyani, P. 2010. Dampak Dan Penanganan Limbah Deterjen. Program Studi Kesehatan Masyarakat Veteriner Fakultas Kedokteran Hewan Institut Pertanian Bogor

[16] Woytowich D.L.; Dalrymple C. W.; Britton M. G.; 1993. Electrocoagulation (CURE) Treatment of Ship Bilgewater for the U. S. Cost Guard in Alaska. Marine Technology Society Journal, Vol. 27. 1p. 62, Spring 1993 